doi: 10.18484/2305-0047.2020.5.597

I. VYNNYCHENKO ${ }^{1}$, M. KONONENKO ${ }^{1}$, O. SMORODSKA $^{1,2}$, S. IVANOV ${ }^{2}$, Y. MOSKALENKO $^{1}$, O. VYNNYCHENKO $^{1}$, V. SIKORA ${ }^{1}$, M. LYNDIN ${ }^{1}$, A. ROMANIUK ${ }^{1}$

\title{
CASE REPORT OF GIANT NONMETASTATIC GASTROINTESTINAL SOLID TUMOR WITHOUT CLINICAL MANIFESTATIONS IN A MIDDLE-AGED MALE PATIENT
}

\author{
Sumy State University ${ }^{1}$, \\ Utility Non-Profit Enterprise Clinical Hospital No5 of Sumy Municipal Council 2, Sumy, \\ Ukraine
}

Гастроинтестинальные стромальные опухоли (ГИСО, GIST) - одни из наиболее часто встречаемых мезенхимальных опухолей, которые происходят из клеток Каяла. Наиболее часто встречающаяся локализация ГИСО - желудочно-кишечный тракт, однако иногда встречаются и внежелудочно-кишечные формы. Большинство ГИСО имеют малый размер, который чаше всего не превышает 5-8 см в максимальном измерении. Данный клинический кейс описывает случай пациента с неметастатической гигантской опухолью желудка без каких-либо клинических проявлений. Опухоль была локализована в брюшной полости, занимая почти всю ее, сдавливая и смещая окружающие органы. Ввиду кистозно-солидной структуры, ее гигантских размеров и интимного прилегания к окружающим органам, провести точную дифференциальную диагностику до оперативного вмешательства не было возможно. Интраоперационная визуализация опухоли, дальнейшие гистологическое и иммуногистохимическое (CD117, CD34, S100, CD45, PanCK; Ki-67) исследования позволили установить диагноз ГИСО желудка T4N0M0, стадия II. На основании полученных данных, несмотря на гигантские размеры, прогноз заболевания был признан благоприятным (низкий митотический индекс, отсутствие метастазирования). За период клинического наблюдения, в течение 1,5 года после оперативного вмешательства, не было зарегистрировано рецидива или прогрессии заболевания, что говорит о благоприятном прогнозе для пациента.

Ключевые слова: опухоль желудка, гастроинтестинальная стромальная опухоль, гигантская опухоль, оперативное лечение

Gastrointestinal stromal tumors (GIST) are one of the most common mesenchymal tumors that originate from the intestinal cells of Cajal. The most common localization of GIST is the gastrointestinal tract, however, extragastrointestinal forms are sometimes found. Most GISTs are small in size, which most often does not exceed $5-8 \mathrm{~cm}$ in maximum dimension. This article describes the case of a patient with a non-metastatic giant tumor of the stomach without any clinical manifestations. The tumor was localized in the abdominal cavity, occupying almost all of it, squeezing and displacing the surrounding organs. Due to the cystic-solid structure, its gigantic size and intimate adherence to the surrounding organs, it was not possible to carry out an accurate differential diagnosis before surgery. Intraoperative imaging of the tumor, further histological and immunohistochemical (CD117, CD34, S100, CD45, PanCK; Ki-67) studies made possible to establish the diagnosis of gastric GIST T4N0M0 stage II. Based on the data obtained, despite the gigantic size, the prognosis of the disease was considered favorable (low mitotic index, no metastasis). During the period of clinical observation, within 1.5 years after surgery, no relapse or disease progression was recorded, which indicates a favorable prognosis for the patient.

Keywords: gastric tumor, gastrointestinal stromal tumor, giant tumor, operative treatment

Novosti Khirurgii. 2020 Jul-Aug; Vol 28 (5): 597-602

Case Report of Giant Nonmetastatic Gastrointestinal Solid Tumor without

Clinical Manifestations in a Middle-Aged Male Patient

I. Vynnychenko, M. Kononenko, O. Smorodska, S. Ivanov, Y. Moskalenko,

The articles published under CC BY NC-ND license

O. Vynnychenko, V. Sikora, M. Lyndin, A. Romaniuk

\section{Introduction}

Today, malignant tumors occupy one of the leading positions in the structure of mortality among the population. This pathology affects all tissues of a living organism and can be localized in various organs and tissues. The literature describes cases of extremely rare oncological diseases that can have difficult-to-predict treatment results [1]. Gastrointestinal stromal tumors (GIST) have a mesenchymal origin occured with a frequency of 10-12-15-20 cases per 1 million people, the average age of patients is $60 \pm 2.9$ years [2, 3, 4, 5]. GIST occurs much more frequently among the male population than among the female population. Tumors originate from intestinal cells of Cajal [6]. 
The most common tumor localizations are: stomach (60-70\%), small intestine (20-30\%), colon and rectum $(5 \%)$, esophagus $(<5 \%)$; cases of GIST localization in the mesentery, omentum, extragastric (so-called extra-gastrointestinal stromal tumors (EGIST)) were also described, although they can occur throughout the gastrointestinal tract $[2,3,4$, $5,7,8]$. GIST sizes are in the range of $1-2-30 \mathrm{~cm}$, most often their size is $<5-8 \mathrm{~cm}$. About $20-30 \%$ of GISTs were discovered by accident, $10 \%$ of which were found during autopsy [6]. Approximately 80 $95 \%$ of these tumors contain the mutant form of the transmembrane tyrosine kinase receptor (Kit), $5-7 \%$ contain platelet growth factor alpha receptor (PDGFR). The diagnostic markers of GIST when using the immunohistochemistry technique are CD117, DOG1 (11q13), theta PCK, CD34, desmin, SMA, S100 [4, 5, 6, 7, 8, 9, 10]. The tactics for treating such neoplasms are as follows: radical removal if the tumor is localized and has no metastases to regional lymph nodes. In the presence of metastases, tumor growth into neighboring structures, in addition to surgical treatment, targeted therapy with imatinibom mesylate (tyrosine kinase inhibitor) is used. If the tumor is resectable, surgical resection is the main choice of treatment regardless of location of the tumor, since complete resection can be performed in $85 \%$ of patients with primary disease $[4,6,11,12]$.

Radiofrequency ablation, as a method of treatment, has shown its effectiveness in cases where surgery is contraindicated or can not be performed. [11].

Objective. To acquaint the medical community with a case of a rare disease having an unusual clinical course (giant non-metastatic GIST), the basics of its course and development, as well as the features of surgical treatment and morphological verification of the diagnosis.

\section{A clinical case}

In January 2019, a 57-year-old patient came to an appointment with complaints of abdominal distension. The symptom appeared after trying to lose weight, when, after increasing physical activity, he noted a reduction in fat mass in all parts of the body except the abdomen, which retained its original size. The patient denied that he had ever used tobacco, alcohol or drugs. On admission, vital signs were normal, saturation was $96 \%$. There were no concomitant diseases. On physical examination, the abdomen retained its shape and size regardless of the position of the patient. Lung examination revealed no abnormalities. The FBC and metabolic panel were unremarkable. Chest X-ray showed no abnormalities. Ultrasound examination showed a giant-sized cystic solid heterogeneous mass
$(29.5 \times 22.0 \times 24.0 \mathrm{~cm})$, presumably derived from bursaomentalis, with a volume of about 8.0 liters. Computed tomography (CT) with contrast in January 2019 revealed a tumor-like formation of giant sizes $(35 \times 32.3 \times 18.7 \mathrm{~cm})$, which has a mixed structure and consists of: a cystic-solid heterogeneous mass, septa and calcifications in the parenchyma, presumably originating from the omentum, comparable to the mesenchymoma , which occupied most of the abdominal cavity. The dense structure was found mainly in the cranial part of the formation. The formation squeezed and displaced the abdominal organs, as well as the retroperitoneal tissue. Metastases were not detected. Due to the structure of the tumor (a huge cystic component), it was decided not to perform a biopsy.

Surgery with radical removal of the tumor was chosen as the method of treatment, so diagnostic studies did not reveal the obvious metastases to distant organs and regional lymph nodes. The operation was performed in February 2019. The access - upper midline laparotomy. Intraoperative findings: the cystic component occupied most of the abdominal cavity; it was decided to evacuate $1 / 3$ of the cyst volume in order to gain better access to the tumor. During the puncture, more than 3 liters of a yellow, cloudy, odorless liquid was obtained. Subsequently, the tumor was separated from the surrounding tissues and organs. The tumor had exophytic growth, a smooth capsule, which was covered with a large omentum on three sides (bottom and sides), and was located on the anterior wall of the stomach along the lesser curvature of the stomach near the the angular notch, and was supplied with blood from the right gastric artery, while no blood supply from omental arteries. There were no technical difficulties during the operation, subserous resection of the tumor was performed, lymph dissection according to the recommendations of AJCC Cancer Staging Manual was not carried out.

Macroscopic description of the tumor: total weight $-12.0 \mathrm{~kg}$ (4.0 kg of solid component and $8.0 \mathrm{~kg}$ of cystic contents), tumor was composed of 4 cavities, that were different from each other (Fig. 1). The tumor mass with multiple areas of necrosis and hemorrhage from the inner wall were revealed on cut surface. After the operation, biopsy with further histological examination was carried out, the morphological results of which corresponded to mesenchymal tumor and GIST.

Histological examination showed that the tumor was represented by elongated spindle-shaped cells with light cytoplasm, some of them had perinuclear clearing (vacuoles).

An epithelioid cell component was found in a significantly smaller portion of the tumor. Among 

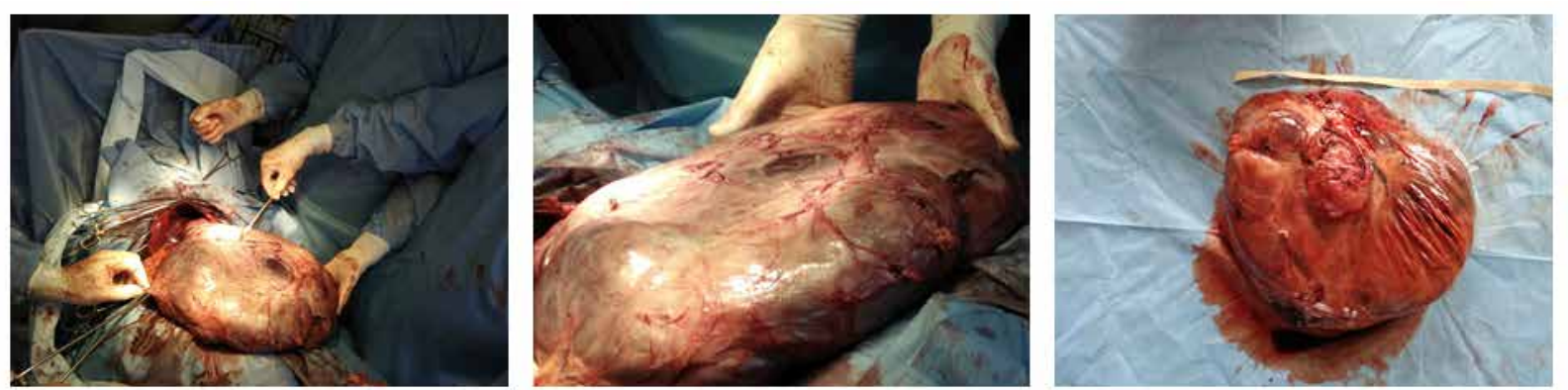

Fig. 1. Gastrointestinal stromal tumor of stomach.

the secondary changes in the tumor, the phenomena of pronounced myxomatosis, hemorrhages, foci of necrosis and hyalinosis were noted. Mitotic activity was low - less than 2 in 50 fields of view (Fig. 2).

To confirm the diagnosis, immunohistochemistry (IHC) was performed, which showed that tumor cells were negative for PanCK, CD45, S100, while CD117, CD34 were positive, the proliferation index (Ki-67 expression) was less than 5\% (fig. 3).

The morphological data corresponded to GIST with a combination of mixed (spindle-epithelioid) variant. Diagnosis: Gastric type of GIST T4N0M0 stage II. Further observation within 18 months did not reveal changes, metastasis and local recurrence of the disease.

Gastrointestinal stromal tumors (GISTs) account for less than $1 \%$ of gastrointestinal tract (GI) tumors, but GIST is the most common mesenchymal tumor in all segments of the GI tract $[2,3,4,5]$. Our patient's age is 57 years old, which correspons to the general epidemiological data. $\mathrm{He}$ had the most common gastric GIST localization, but fortunately our patient was not included in a quarter of patients with metastatic disease and clinically aggressive disease.

It seems strange that a huge tumor did not have any clinical manifestations such as gastrointestinal bleeding, gastrointestinal obstruction, fatigue, dysphagia or chronic anemia, which are most common in this type of tumor $[4,5]$. Computed tomography was used to diagnose and confirm GIST. Endoscopic ultrasound examination with fine needle aspiration biopsy was not performed to determine the type of tumor due to its exophytic growth and huge cystic component in order not to destroy the tumor and prevent its possible further spread.

Open surgery remains the preferred procedure due to the size of the tumor and the huge cystic component, but laparoscopic surgery is the method of choice for tumors less than $5-10 \mathrm{~cm}$. Histological study showed a combination of spindle-shaped and epithelioid variants, which is detected in only $10 \%$ of patients [10]. The final diagnosis was made only after positive expression of CD117 and CD34 had been revealed in tumor cells.

However, in this case, special attention should be paid to the molecular behavior of the tumor (mitotic activity, proliferation index, size and location, immune microenvironment, angiogenesis, etc.), which can be very helpful in choosing a treatment regimen $[4,7,10,13]$.

Based on the data obtained, the patient has a moderate risk of disease progression - about $12 \%$ [14]. CT scan of the abdominal cavity / pelvic organs with an interval of 3 months was used as control studies and to monitor the patient's condition in the postoperative period. During the entire observation period, no relapse, local and distant metastases were detected, which, in turn, made it possible to judge a positive result of treatment.

\section{Conclusion}

The clinical picture of a gastrointestinal stromal tumor may be atypical, which greatly complicates the correct diagnosis.

In the presented case, the final diagnosis was possible in case of comprehensive analysis of the results of instrumental diagnostics (ultrasound and $\mathrm{CT}$ ), surgical intervention (tumor resection), his-

Fig. 2. Gastrointestinal stromal tumor of stomach. Hematoxylineand Eosinstaining. Magnification: $A \times 40 ; B \times 100 ; C \times 400$
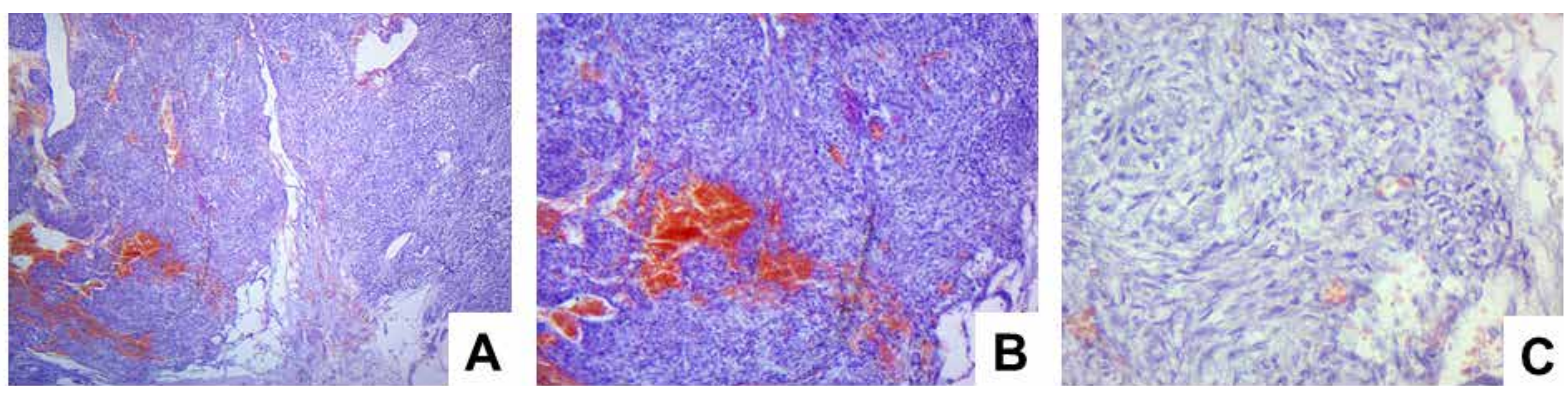

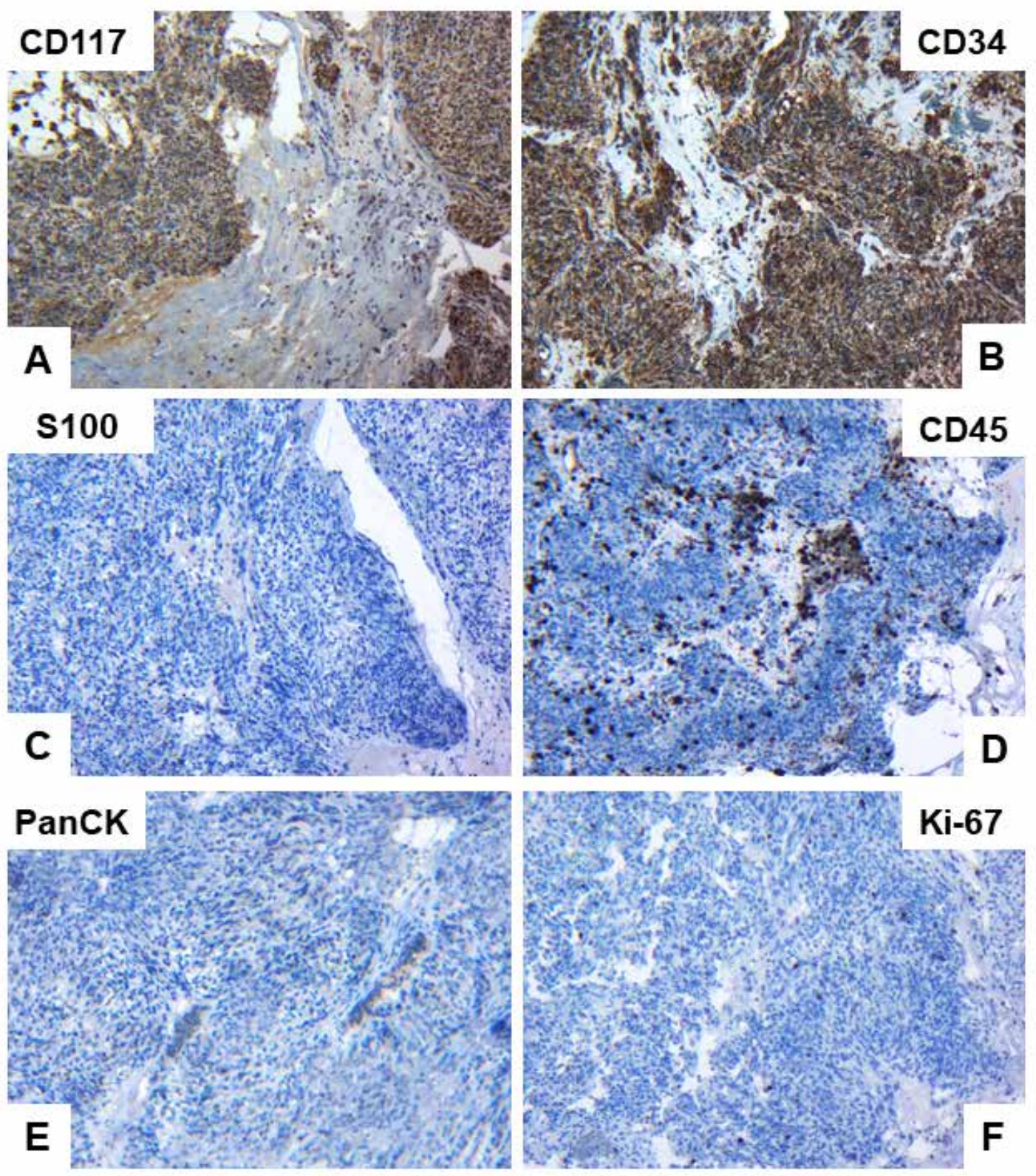

Fig. 3. Gastrointestinal stromal tumor of stomach. Immunohistochemical examination of CD117(A), CD34 (B), S100 (C), CD45 (D), PanCK (E)and Ki-67 (F) expression. Magnification $\times 400$.

tological and immunohistochemical study: positive expression of CD117 and CD34; a Ki67 proliferation index less than 5\%; negative expression of S100, CD45, PanCK.

Morphological findings matched with GIST with a combination of mixed (spindle-epithelioid) variant.

Diagnosis: Gastric type of GIST T4N0M0 stage II. Within 18 months of observation, no relapses and disease progression were recorded, which indicates a favorable prognosis for the patient.

\section{Funding}

The study was carried out in accordance with the plan of scientific research of the Department of Oncology and Radiology, and the Department of Pathological Anatomy of the Medical Institute of Sumy State University, as well as within the framework of the grant of the Ministry of Education and Science of Ukraine No. 62.14-01.18 / 20. (The effectiveness of "liquid biopsy" and tissue biopsy in the diagnosis and treatment of malignant tumors). The authors did not receive financial support from drug manufacturers.

\section{Conflict of interest}

The authors declare about the absence of conflict of interest. 


\section{Ethical aspects Ethics committee approval}

The work was approved by the Committee on the Ethics of the Medical Institute of Sumy State University

\section{Informed consent}

The patient consented to the publication of the message and the posting on the Internet of information about the nature of his disease, the treatment performed and its results for scientific and educational purposes.

\section{ЛИТЕРАТУРА}

1. Romaniuk A, Lyndin M, Smiyanov V, Sikora V, RieznikA, Kuzenko Y, Budko H, Moskalenko Y, Karpenko L, Sikora V, Gladchenko O. Primary multiple tumor with affection of the thyroid gland, uterus, urinary bladder, mammary gland and other organs. Pathol Res Pract. 2017 May;213(5):574-79. doi: 10.1016/j.prp.2017.01.003 2. Corless CL, Heinrich MC. Molecular pathobiology of gastrointestinal stromal sarcomas. Аnnu Rev Pathol. 2008;3:557-86. doi: 10.1146/annurev.pathmechdis.3.121806.151538

3. Joensuu H, Hohenberger P, Corless CL. Gastrointestinal stromal tumour. Lancet. 2013 Sep 14;382(9896):97383. doi: 10.1016/S0140-6736(13)60106-3

4. Laurini JA, Carter JE. Gastrointestinal stromal tumors: a review of the literature. Arch Pathol Lab Med. 2010 Jan;134(1):134-41. doi: 10.1043/2008-0083-RSR2.1

5. Miettinen M, Lasota J. Gastrointestinal stromal tumors - definition, clinical, histological, immunohistochemical, and molecular genetic features and differential diagnosis. Virchows Arch. 2001 Jan;438(1):1-12. doi: 10.1007/ s004280000338

6. Obinero C, Makar GS, Rowe JS, Makar MS, Holdbrook T, Hageboutros A, Spitz FR, Kovacs JE. Large incidental gastrointestinal stromal tumors in a patient presenting with acutely symptomatic nephrolithiasis: A case report. Radiol Case Rep. 2019 Feb 26;14(5):555-60. doi: 10.1016/j.radcr.2019.02.005. eCollection 2019 May.

7. Sahu KK, Tapadia R, Kini JR, Pai RR, Kini H, Nirupama M, Pooja KS. Discovered on gastrointestinal stromal tumor 1, a keystone in the diagnosis of extraintestinal gastrointestinal stromal tumors. J Cancer Res Ther. 2019 Jan-Mar;15(1):138-41. doi: 10.4103/jcrt.JCRT 2817

8. Alghamdi HM, Amr SS, Shawarby MA, Sheikh SS, Alsayyah AA, Alamri AM, Ismail MH, Almarhabi A, Alrefaee MA, Ahmed MI. Gastrointestinal stromal tumors. A clinicopathological study. Saudi Med J. 2019 Feb;40(2):126-30. doi: 10.15537/smj.2019.2.23913

9. Etherington MS, DeMatteo RP. Tailored management of primary gastrointestinal stromal tumors. Cancer. 2019 Apr 1. doi: $10.1002 /$ cncr.32067

10. Wang Y, Call J. Mutational Testing in Gastrointestinal Stromal Tumor. Curr Cancer Drug Targets. 2019;19(9):688-697. doi: 10.2174/1568009619666190326 123945

11. Parab TM, DeRogatis MJ, Boaz AM, Grasso SA, Issack PS, Duarte DA, Urayeneza O, Vahdat S, Qiao JH, Hinika G. Gastrointestinal stromal tumors: a comprehensive review. J Gastrointest Oncol. 2019 Feb;10(1):14454. doi: $10.21037 /$ jgo.2018.08.20
12. Iwatsuki M, Harada K, Iwagami S, Eto K, Ishimoto T, Baba Y, Yoshida N, Ajani JA, Baba H. Neoadjuvant and adjuvant therapy for gastrointestinal stromal tumors. Ann Gastroenterol Surg. 2018 Sep 27;3(1):43-49. doi: 10.1002/ags3.12211. eCollection 2019 Jan.

13. Romaniuk A, Lyndin M, Sikora V, Lyndina Y, Panasovska K. Histological and immunohistochemical features of medullary breast cancer. Folia Med Cracov. 2015;55(2):41-48.

14. Gastrointestinal Stromal Tumors Treatment (PDQ $\left.{ }^{\circledR}\right)-$ Health Professional Version [Internet]. Available from: https://www.cancer.gov/types/soft-tissue-sarcoma/hp/ gist-treatment-pdo

\section{REFERENCES}

1. Romaniuk A, Lyndin M, Smiyanov V, Sikora V, RieznikA, Kuzenko Y, Budko H, Moskalenko Y, Karpenko L, Sikora V, Gladchenko O. Primary multiple tumor with affection of the thyroid gland, uterus, urinary bladder, mammary gland and other organs. Pathol Res Pract. 2017 May;213(5):574-79. doi: 10.1016/j.prp.2017.01.003

2. Corless CL, Heinrich MC. Molecular pathobiology of gastrointestinal stromal sarcomas. Annu Rev Pathol. 2008;3:557-86. doi: 10.1146/annurev.pathmechdis.3.121806.151538

3. Joensuu H, Hohenberger P, Corless CL. Gastrointestinal stromal tumour. Lancet. 2013 Sep 14;382(9896):97383. doi: 10.1016/S0140-6736(13)60106-3

4. Laurini JA, Carter JE. Gastrointestinal stromal tumors: a review of the literature. Arch Pathol Lab Med. 2010 Jan;134(1):134-41. doi: 10.1043/2008-0083-RSR2.1

5. Miettinen M, Lasota J. Gastrointestinal stromal tumors - definition, clinical, histological, immunohistochemical, and molecular genetic features and differential diagnosis. Virchows Arch. 2001 Jan;438(1):1-12. doi: 10.1007/ s004280000338

6. Obinero C, Makar GS, Rowe JS, Makar MS, Holdbrook T, Hageboutros A, Spitz FR, Kovacs JE. Large incidental gastrointestinal stromal tumors in a patient presenting with acutely symptomatic nephrolithiasis: A case report. Radiol Case Rep. 2019 Feb 26;14(5):555-60. doi: 10.1016/j.radcr.2019.02.005. eCollection 2019 May.

7. Sahu KK, Tapadia R, Kini JR, Pai RR, Kini H, Nirupama M, Pooja KS. Discovered on gastrointestinal stromal tumor 1 , a keystone in the diagnosis of extraintestinal gastrointestinal stromal tumors. J Cancer Res Ther. 2019 Jan-Mar;15(1):138-41. doi: 10.4103/jcrt.JCRT 2817

8. Alghamdi HM, Amr SS, Shawarby MA, Sheikh SS, Alsayyah AA, Alamri AM, Ismail MH, Almarhabi A, Alrefaee MA, Ahmed MI. Gastrointestinal stromal tumors. A clinicopathological study. Saudi Med J. 2019 Feb;40(2):126-30. doi: 10.15537/smj.2019.2.23913

9. Etherington MS, DeMatteo RP. Tailored management of primary gastrointestinal stromal tumors. Cancer. 2019 Apr 1. doi: $10.1002 /$ cncr.32067

10. Wang Y, Call J. Mutational Testing in Gastrointestinal Stromal Tumor. Curr Cancer Drug Targets. 2019;19(9):688-697. doi: 10.2174/1568009619666190326 123945

11. Parab TM, DeRogatis MJ, Boaz AM, Grasso SA, Issack PS, Duarte DA, Urayeneza O, Vahdat S, Qiao JH, Hinika G. Gastrointestinal stromal tumors: a comprehensive review. J Gastrointest Oncol. 2019 Feb;10(1):14454. doi: 10.21037 /jgo.2018.08.20

12. Iwatsuki M, Harada $\mathrm{K}$, Iwagami $\mathrm{S}$, Eto $\mathrm{K}$, Ishimoto T, Baba Y, Yoshida N, Ajani JA, Baba H. Neoadjuvant and adjuvant therapy for gastrointestinal stromal tum- 
ors. Ann Gastroenterol Surg. 2018 Sep 27;3(1):43-49. doi: 10.1002/ags3.12211. eCollection 2019 Jan.

13. Romaniuk A, Lyndin M, Sikora V, Lyndina Y, Panasovska K. Histological and immunohistochemical features of medullary breast cancer. Folia Med Cracov.

\section{Адрес для корреспонденции}

40022, Украина,

г. Сумы, ул. Привокзальная, д. 31,

Медицинский институт

Сумского государственного университета,

кафедра онкологии и радиологии,

тел.: +380958000489,

e-mail: smorodska1991@gmail.com,

Смородская Ольга Николаевна

\section{Сведения об авторах}

Винниченко Игорь Александрович, к.м.н., доцент, заведующий кафедрой онкологии и радиологии, Медицинский институт Сумского государственного университета, г. Сумы, Украина.

http://orcid.org/0000-0002-2339-6509

Кононенко Николай Григорьевич, д.м.н., профессор кафедры хирургии, Медицинский институт Сумского государственного университета, г. Сумы, Украина.

http://orcid.org/0000-0003-3068-1751

Смородская Ольга Николаевна, аспирант кафедры онкологии и радиологии, Медицинский институтСумского государственного университета, г. Сумы, Украина, врач-хирург, Клиническая больница №5, г. Сумы, Украина.

http://orcid.org/0000-0002-9028-3379

Иванов Станислав Сергеевич, врач-хирург, Клиническая больница №5, г. Сумы, Украина. http://orcid.org/0000-0001-8897-0041

Москаленко Юлия Васильевна, к.м.н., ассистент кафедры онкологии и радиологии, Медицинский институт Сумского государственного университета, г. Сумы, Украина.

http://orcid.org/0000-0002-5398-0298

Винниченко Александр Игоревич , к.м.н., ассистент кафедры онкологии и радиологии, Медицинский институт Сумского государственного университета, г. Сумы, Украина.

http://orcid.org/0000-0001-5651-0323

Сикора Владислав Владимирович, к.м.н., ассистент кафедры патологической анатомии, Медицинский институт Сумского государственного университета, г. Сумы, Украина.

http://orcid.org/0000-0002-4147-6879

Лындин Николай Сергеевич, к.м.н., ассистент кафедры патологической анатомии, Медицинский институт Сумского государственного университета, г. Сумы, Украина.

http://orcid.org/0000-0003-4385-3903

Романюк Анатолий Николаевич, д.м.н., профессор, заведующий кафедрой патологической анатомии, Медицинский институт Сумского государственного университета, г. Сумы, Украина.

http://orcid.org/0000-0003-2560-1382

\section{Информация о статье}

Поступила 21 января 2020 г.

Принята в печать 5 октября 2020 г.

Доступна на сайте 1 ноября 2020 г.
2015;55(2):41-48.

14. Gastrointestinal Stromal Tumors Treatment (PDQ $\left.{ }^{\circledR}\right)-$ Health Professional Version [Internet]. Available from: https://www.cancer.gov/types/soft-tissue-sarcoma/hp/ gist-treatment-pdq

\section{Address for correspondence}

40022, Ukraine,

Sumy, Privokzalnaya str., 31,

Medical Institute of Sumy State

Medical University, the Department

of Oncology and Radiology,

tel.: +380958000 489,

e-mail: smorodska1991@gmail.com,

Smorodska Olga N.

\section{Information about the authors}

Vynnychenko Ihor A., PhD, Associate Professor, Head of the Department of Oncology and Radiology, Medical Institute of Sumy State Medical University, Sumy, Ukraine.

http://orcid.org/0000-0002-2339-6509

Kononenko Mykola G., MD, Professor of the Surgery Department, Medical Institute of Sumy State Medical University, Sumy, Ukraine.

http://orcid.org/0000-0003-3068-1751

Smorodska Olga N., Post-Graduate Student of the Department of Oncology and Radiology, Medical Institute of Sumy State Medical University, Surgeon, Clinical Hospital No5, Sumy, Ukraine.

http://orcid.org/0000-0002-9028-3379

Ivanov StanislavS., Surgeon, Clinical Hospital No5, Sumy, Ukraine.

http://orcid.org/0000-0001-8897-0041

MoskalenkoYuliia V., PhD, Assistant of the Department of Oncology and Radiology, Medical Institute of Sumy State Medical University, Sumy, Ukraine.

http://orcid.org/0000-0002-5398-0298

Vynnychenko Oleksandr I., PhD, Assistant of the Department of Oncology and Radiology, Medical Institute of Sumy State Medical University, Sumy, Ukraine.

http://orcid.org/0000-0001-5651-0323

Sikora Vladyslav V., PhD, Assistant of the Pathologic Anatomy Department, Medical Institute of Sumy State Medical University, Sumy, Ukraine.

http://orcid.org/0000-0002-4147-6879

Lyndin Mykola S., PhD, Assistant of the Pathologic Anatomy Department, Medical Institute of Sumy State Medical University, Sumy, Ukraine.

http://orcid.org/0000-0003-4385-3903

Romaniuk Anatolii N., MD, Professor, Head of the Pathologic Anatomy Department, Medical Institute of Sumy State Medical University, Sumy, Ukraine.

http://orcid.org/0000-0003-2560-1382

\section{Article history}

Arrived: 21 January 2020

Accepted for publication: 5 October 2020

Available online: 1 November 2020 